\title{
What Millennial Workers Want? Turnover or Intention to Stay in Company
}

\author{
Mappamiring MAPPAMIRING ${ }^{1}$, Muhammad AKOB ${ }^{2}$, Aditya Halim Perdana Kusuma PUTRA ${ }^{3}$
}

Received: March 07, 2020 Revised: March 21, 2020 Accepted: April 03, 2020

\begin{abstract}
The purpose of this study is to investigate and reconfirm the research instruments and variables that have been developed by prior study and built new concepts from empirical research results. Besides analyzing the essential role of fundamental, rational, and psychology aspects to increase employee's intention to stay in a company, which is useful for the development of human resource development strategies for millennial workers in the future. A total of 438 non-student male respondents aged 23-36 years, with unmarried status and not working in the SOE sector or as a civil servant, were surveyed with questionnaires. The study was conducted in Makassar, Indonesia. Data collection uses a survey with the second-order model approach and regression with control variables. The findings of this study suggest the existence of an inter-relationship between fundamental, rational and psychological aspects. They are inseparable and have a positive and significant influence. Broadly speaking, the link between fundamental, psychology and rational aspects states that the decision for millennial male workers to stay in the company will depend on whether the company has a good image and reputation, the level of attention the organization pays to career development, is competent, and applies regulations and rules with flexibility.
\end{abstract}

Keywords : Stay Intention, Social Study, Behavior Study, Human Resource Management

JEL Classification Code: M0, M54, E24

\section{Introduction}

Humans as social beings explicitly act and make decisions through three primary considerations, namely, rational, normative and psychological considerations (Indahingwati, Launtu, Tamsah, Firman, Putra, \& Aswari, 2019), in which the three elements are mutually related, and their respective dominance of the decision to be taken that are included in

${ }^{1}$ First Author and Corresponding Author. Associate Professor, Department of Management, STIEM Bongaya, Makassar, Indonesia [Postal Address: Jalan. Let. Jend. Mappaoddang No.28, Bongaya, Kec. Tamalate, Kota Makassar, Sulawesi Selatan 90131, Indonesia] Email: mappamiring.mappamiring@gmail.com

${ }^{2}$ Associate Professor Department of Management, STIEM Bongaya, Makassar, Indonesia

${ }^{3}$ Assitant Professor, Department of Management, Faculty of Economics and Business, Universitas Muslim Indonesia,

Makassar, Indonesia. Email: adityatrojhan@gmail.com

(c) Copyright: The Author(s)

This is an Open Access article distributed under the terms of the Creative Commons Attribution Non-Commercial License (http://Creativecommons.org/licenses/by-nc/4.0/) which permits unrestricted noncommercial use, distribution, and reproduction in any medium, provided the original work is properly cited. choosing to remain working at a company. There are various situations and conditions that make workers decide to leave the company where they work. The company deploys various efforts and strategies to retain employees who they think are competent and valuable to the company. Efforts to improve the standard of living of employees in the form of salary increases, bonuses and provision of facilities aimed at making workers desirous to stay in a company are common steps taken by many HRM managers. However, it is not uncommon to find that many of the employees finally decide to resign even though, if observed in terms of salary and position, they have been in a situation dreamed of by many people. In the end, each human being will be loyal to himself to find something ideal, appropriate, and make them comfortable and calm.

In a competitive situation, it is disastrous for the company to abandon employees who have potential; the company needs reforms to recruit and build bridges, and provides a vision and a mission that employees perceive to be positive. This process is not an easy one to undertake. As a productive generation in this era, millennials play a vital role in all sectors; today's development and the rapid use of technology also helped to challenge the behavior of the millennial generation towards 
the previous generation. Not infrequently, millennials are faced with negative stigmas, ranging from lifestyles and behavioral patterns, which are predicted to have a negative impact in the future. One of the negative assumptions of the previous generations that still survive (baby-boomers and generation $\mathrm{X}$ ) sometimes assumes that the millennial is a generation that is undisciplined, unprofessional and disloyal. However, of the many lists of notes and wrong predictions from millennial generation, it also shows some positive reviews and summaries. Some studies in psychology have found that millennials emphasize individualism, have views about career advancement and development and skills $(\mathrm{Ng}$, Schweitzer, \& Lyons, 2010), are socially responsible in terms of respecting friendship (Borges, Manuel, Elam, \& Jones, 2010), are oriented toward teamwork (Myers \& Sadaghiani, 2010) demand transparency in the management (Lowe, Levitt, \& Wilson, 2011), are creative in terms of information gathering, and have sensitivity in analyzing and detecting problems (Gursoy, Maier, \& Chi, 2008)

Millennials are the final group that enjoys analog technology, but at the same time, opens up to digital technology, so that the behavior and habits exhibited in daily life also shift compared to previous generations. Problems that occur in the current management order: the millennial group is still in the position at the bottom to middle management, generation X (born in 1961-1980) occupies the middle to upper management, and the baby-boomers generation (born before 1960) holds the top position in management. This difference in management level certainly creates a gap. One of the gaps is the gap between expectations and reality between generation $\mathrm{X}$ and baby-boomers towards millennials. Some forms of gap include defining the meaning of the words discipline, work, work motivation, loyalty, and engagement with different intentions and goals.

Kumar and Govindarajo, (2014) has compiled several instruments regarding employee's intention to stay in the world of employment. The results of the literature review contain twenty-four indicator variables. Kumar's results (2014) found that work environment factors were the most dominant factors in determining employee job satisfaction and decisions for the intention to stay. This study is a duplication of existing study rather than an instrument developed by Kumar. More specifically, the difference between this study and Kumar's research is that this study maps instruments based on behavioral and social theory categories and with a middle-range theory approach rather than behavioral judgment studies, which state that humans make decisions through three primary considerations, namely, the principle of rationality, normative and the principle of psychology. So, this study of the instrument is shaped by the fundamental aspect of construction, rational, and psychology aspects.
This study investigates and reconfirms the research instruments that have been developed previously and builds new concepts from empirical research models. Specifically, Apart from that, the objective of this study is to analyze the essence and role of the fundamental aspects, rational aspects, and psychology aspects to increase the millennial employees' intention to stay. Starting from social theory, behavioral theory, and modern motivational theory, this study intends to develop critical reviews to enrich the perspectives of HRM managers that are useful for developing human resource strategies for millennial workers in the future.

\section{Literature Review and Hypothesis}

Humans, as complex social beings, have relationships, one of which consists of logical and emotional units. Creating comfort in each person's self requires a process that is certainly not easy and fast. Included in the process is the creation of a comfortable atmosphere in the work environment. The social and psychological aspects of humans, one of the driving forces of the company, have been widely studied. There are social theories of behavior such as social learning theory, then evolving into social contagion, and behavioral theory from Gustave Le Bon, Robert Park, Helbert Blumer (McPhail, 1989), and the stimulus-organizational-respond theory (SOR), which examines how the surrounding environment can influence personal behavior (Spence, 1950; Koffka, 2013). Specifically, Le Bon states that personal behavior can be formed through social interaction. The process of social interaction involves emotions, which as the end of the communication can shape perceptions of likes or dislikes, feelings of comfort or discomfort. It is not much different from what was expressed by Park, where social contagion was born from the effects by action to cause a reaction. Park also added that every member of his group could accept the structure of a person's behavior, which is considered to be subjectively correct (McPhail, 1989). What is very abstract in humans is the study of feelings and psychology, including the components to create feelings of pleasure, happiness, and comfort, both as members of the community-led and as leaders in their social environment. Sometimes differences in perception and miscommunication often give birth to dynamics amid groups/organizations. The expectation to be realized sometimes makes it difficult for a person or group to reach a point of agreement to unify multi-person desires, perceptions, visions, and missions; the gap between expectations and reality is defined as a problem.

This study maps the concept of intention to stay variable, which is reflected in three aspects, i.e., psychology aspect, which contains several items such as bullying effect, job satisfaction, desire to self-actualize, and organizational 
image. The definition of a bully is an intentional act or aggressive behavior, carried out by a person or group repeatedly from time to time to someone who is considered weak (Olweus \& Limber, 2010). Jennifer, Cowie, and Ananiadou (2003), Saam (2010) and Bartlett and Bartlett, (2011) state that bullies are not only physical, but also psychological violence, causing an imbalance in physical, cognitive strength. Bullies are broadly divided into four types, namely bullies verbally, physically, and bully in a relational way such as systematically weakening one's self-esteem, including neglect, exclusion, and avoidance of others. (Coloroso, 2006). Coetzee and van Dyk (2017) specifically examine the impact of bullying on work engagement with the social cognitive theory and found that bullying has a significant effect on employee engagement and turnover intention on the organization. The impact of bullies is also a potential moderator variable that determines employee decisions for intention to stay (Bahjat, Aljawazneh, Moh, Smadi, \& Ziad, 2017). Both of these studies were later strengthened by (Rosario, Millán, Ramos, Cruz, Vélez, Torres, \& Rodríguez, 2018) where the interrelated effects created by bully behavior can cause decreased job satisfaction, work engagement and stress.

The second item in the psychological aspect is job satisfaction, which is a reflection of the general attitude of an individual to his work (Robbins, 2002). Job satisfaction can be achieved if the work is challenging; there are rewards, working environment conditions, and interpersonal relationships in an organization. (Robbins \& Judge, 2008). Study by Zhang, Ma, Xu, and Xu (2019) confirmed Robbins's statement (2002) where there is a complicated relationship between job satisfaction, a work environment that makes employees feel comfortable and decides to be loyal to their work. Even fairness in the organization will determine whether employees will stay or leave their company (Bayarcelik \& Findikli, 2016). Decisions for the intention to stay are also influenced and mediated by job satisfaction, but aspects of the workplace relationship quality do not impact on plans to remain as much as the impact of training and development (Sharma \& Stol, 2020). Psychologically, the effect of regulation and flexible rules in providing socialization space for employees with their social life in the workplace and their environment has an extreme impact (Wang, Hom, \& Allen, 2017; MacIntosh \& Doherty, 2010). Even socialization makes it easy for companies or organizations to integrate knowledge, expand understanding of the company's vision and mission for employees in a comprehensive manner, so that socialization can be used as a form of internal company innovation to increase engagement and job satisfaction, and employee intention to stay (Dingler \& Enkel, 2016). Explicitly, when someone joins an organization, they will re-evaluate the situation in the organization, and the interpretation of the results of the evaluation will be returned to their original goals to provide definite conclusions, feelings to stay, intention to stay or contrary feelings (intention to leave).

From the rational aspect point of view, this study developed several constructs. Among them are the issues of wage and salary, workload, flexible regulation and rules, training and development, and access location which are claimed to have an impact on an employee's decision to stay in the company where they work. Holtemöller and Pohle, (2019) examining, in Germany, the regulations regarding wage and salary in terms of economic policy, found that the differences in wages and salary among employees have an impact on work productivity. Wage and salary also affect job satisfaction, work motivation and perceived quality of life (Ahmat, Arendt, \& Russell, 2019; Emiroğlu, Akova, \& Tanriverdi, 2015). Wages or salaries are closely related because it is a right and a measure of the results achieved from work done. Rational humans work to meet natural needs such as primary, secondary and tertiary needs. The level of wages of workers is closely related to the level of productivity, some studies even state that remuneration is the main reason that determines workers' loyalty or lack of it (Lee \& Wilbur, 1985). Usually, the higher the productivity of workers, the higher the level of wages. The workload also has a positive impact on productivity, which results in employee engagement and work intention. Workload analysis is the process of determining the number of hours worked by employees aimed at workloads that are distributed evenly and appropriately. Workload analysis goes through several approaches and requirements. Workload analysis can be based on physical skills, abilities, and experience or on position and administrative requirements. Hierarchically, there is a strong relationship between employee engagement and workload, which can have positive and negative impacts (Goh, Ilies, \& Wilson, 2015; Kokoroko \& Sanda, 2019; Shao, Nijstad, \& Täuber, 2019). Apart from that, from a fundamental point of view, the regulatory flexibility issue and rules affect employees and the organization. Burdin and Pérotin, (2019) examine work-time flexibility in the private sector industry in a cross-country study. Burdin (2019) states that the working time flexibility factor has a positive and significant effect on the organization. Even deviant behavior, which states that the reason why employees break the rules is influenced by inflexible work rules (Ghosh \& Shum, 2019). An understanding of the psychological state of employees in organizations, specifically about working time flexibility, is needed to retain potential employees. (Walsh, 2019).

Furthermore, in aspects to realize job satisfaction and expectations to create positive feelings rather than employees, HR training and development in a company is very carefully related to the performance results of this 
HR. Human resources (HR) or employees who occupy a particular position in the company sometimes have different levels of ability with other employees. Sometimes their skills increase, but sometimes they also decrease. There are also those whose talents are not following the requirements needed in the position. That can happen because someone occupies a specific position, not because of his ability. Therefore, new employees need to increase their skills and abilities. That is the importance of employee training. Proper HR training and development can have a good effect on employees. Jaworski, Ravichandran, Karpinski, and Singh (2018) stated that training has a significant impact on employee competency development, so that it also affects job satisfaction and commitment to their work. Job satisfaction, loyalty, and desire for intention to stay at the office are also inseparable from external factors such as the distance between the residence and the office. A study states that the longer the home-office travel time, the less time to establish social relationships that will affect the level of health and happiness.

The third aspect of this study raised several measurement constructs, one of which is leadership management, supervisors, and leadership factors. Leadership theory and organizational theory are essential instruments in carrying out activities in organizations (Stogdill, 1974). Leadership within the organization needs to be owned by all internal members of the organization, whatever the vision and mission of the organization or company. Therefore, an organization or company needs a leader figure who can be an example for other internal members of the organization. Leadership is the process of influencing existing activities, specifically to carry out an organization within a group as one of the efforts to be able to achieve goals (Mitchell
\& Scott, 1987). Pigors, in his book "Leadership and Domination," sees leadership is an encouraging process that controls human usability in pursuing a common goal, through successful interactions of various kinds of individual differences (Pigors, 1933; Meiyani \& Putra, 2019). The leadership style that is not appreciated by the employees can cause stress and lead to employee turnover intention towards the organization (Elci, Aksoy, \& Alpkan, 2012). So, the definition of leadership is more friendship, transparent in the communication, and fair in providing rewards and compensation to employees (Brown, Trevino, \& Harrison, 2005). Furthermore, a pleasant work environment will be able to cause colleagues to support each other to complete the work assigned to them, so that later a conducive work environment will create satisfaction for employees and will produce an excellent performance for the company (Jiang \& Shen, 2018). Employee satisfaction plays an essential role in organizational success, when employee satisfaction is high it can reduce turnover and can improve employee morale (Li, Zhang, Xiao, Chen, \& Lu, 2019; Chung, Jung, \& Sohn, 2017). Safety and security factors during work (Sharma \& Stol, 2020), health facility (Amponsah, Ntow, \& Mensah, 2016), welfare service and turnover (Kim \& Kao, 2014; Chen, Park, \& Park, 2012) all become components of fundamental aspects that determine employees' intention to stay or plans to leave.

Based on the arguments presented in the introduction, prior research, and the literature review, the theoretical framework of this research can be described in Figure 1. We formulate the following hypothesis:

Psychological, fundamental and rational aspects have a positive effect and can generate intention to stay variables.

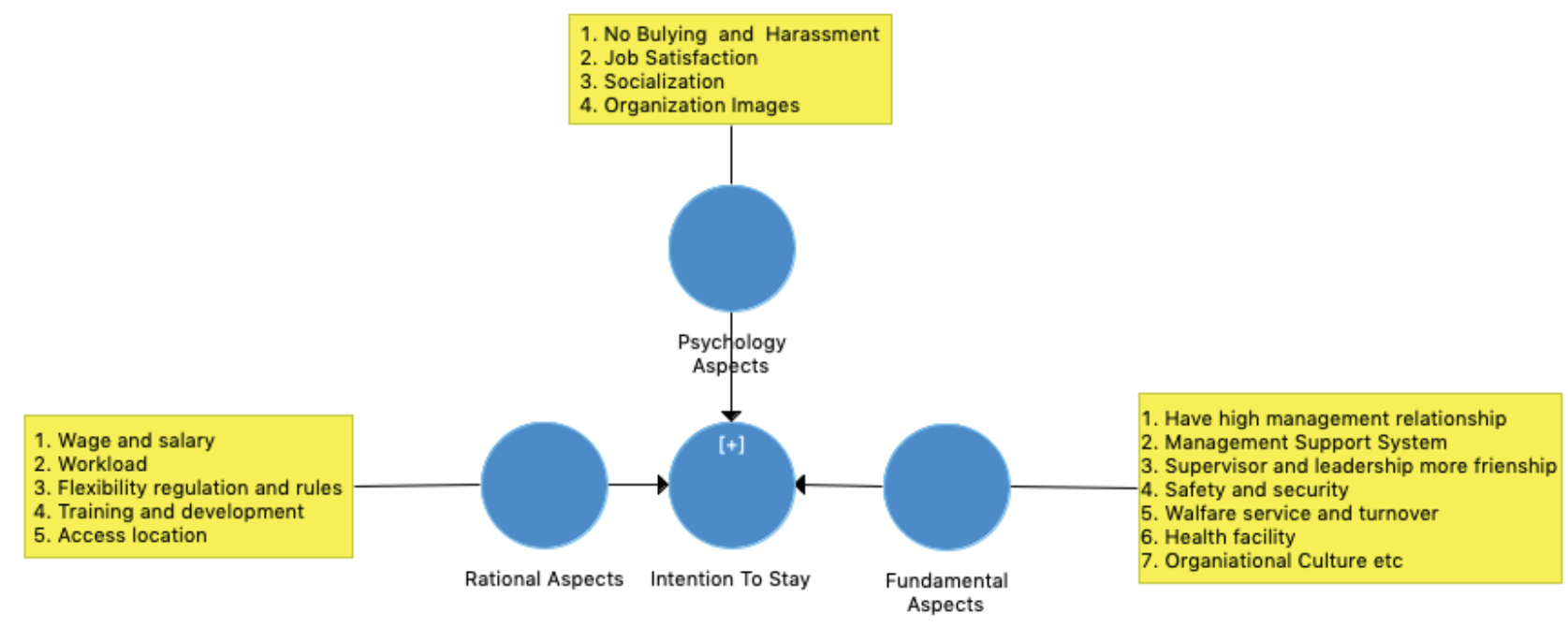

Figure 1: Conceptual Framework 


\section{Research Design and Methodology}

\subsection{Samples}

This study involved 438 respondents who are male nonstudent aged between 26 and 33 years and not married, without entering the level of education level and also not entering the level of income. The sample criteria also do not allow samples that have the status of civil servants or those who work in SOEs. Generally, respondents are those who work in private companies or small companies, either as permanent employees or part-time employees. The study period takes place between July and October 2019 in Makassar City, Indonesia. The sampling method uses random purposive sampling.

\subsection{Data Collection Procedure and Measurement}

Data collection using surveys (field survey and online survey), measurement of variables, and constructs using the Likert scale 1-7 (strongly disagree - strongly agree). The analysis looks at constructs through several stages, namely, testing the validity of the discriminant validity method using smart pls, testing the normality of the Kolmogorov-Smirnov process by assessing the significance of asymptotic value using SPSS, and normality testing data using residual data. Conceptual measurements through the second-order model also use SPSS. The analysis uses control variables with SPSS. Constructions, items, and variables are explained in Appendix 1.

\section{Results and Discussion}

The second-order model as described in Appendix 2 shows the Cronbach alpha value as a whole is at a high level (above 0.60), so that it has met the assumptions of data reliability testing. (Chin, 1998) constructs loadings also indicating a value $>60$, testing the validity of the study instrument shows a dominant $>60$ so that it can be concluded that it has fulfilled the research assumptions (Fornell \& Larcker, 1981). The construct of multicollinearity testing (VIF) states that all constructs are at level $<5.0$ so that it can be universally stated that the second-order model testing has fulfilled the requirements and is eligible.

Appendix 3 explains the items forming the intention-to-stay variables and can be interpreted that the dominant construct that influences the shaping of the item psychology aspect variable. It is the item (IP8 = 41.45). In contrast, the fundamental element of the dominant aspect is formed by the construct (IF7 $=28.391$ ). In the rational aspect item, dominant is formed by construct (IR3 $=17,081)$. It can be explicitly described based on the value of the influence that psychologically, the desire or intention of millennial employees to stay afloat in the job profession is mainly due to the image factor of the organization/ company where they work $($ IP8 $=41.48)$. The second reason is the factor of job satisfaction (IP6 = 17,764); third, is the factor of the lack of bullying and harassment $(\mathrm{IP} 2=17,516)$; fourth is the factor of desire and allowance of time to have the opportunity to enjoy social life (IP7 $=15,546$ ).

Several constructs primarily form the fundamental aspect dimension as a factor, as well as the reason why an employee decides to remain in-stay in his organization/company. Based on the ranking of the influence value (t-statistic) in this study, it shows that: the fundamental career development factors are the top priority (IF7 $=28,391)$; second is the reason for the humanistic/friendship leadership pattern (IF3 $=27,976)$; third comes the safety and security factor in the work environment (IF4 $=23,130)$; fourth is management support system factors (IF2 = 13,969); fifth, the health facility factor (IF6 = 9,065); sixth is the relationship factor between internal management or harmony at work $(\mathrm{IF} 1=8,883)$; and seventh is welfare service and turnover factors (IF5 $=8.258$ ). As regards the rational aspect, the flexibility factor regulation and rules Item (IR3 = 17,081) are the dominant item forming the rational dimension aspect of a reason why employees decide to stay-intention to work in their office. Second is the workload factor (IR2 $=16,799)$. The third is the training and development factor $(\mathrm{IR} 4=14,767)$. Fourth, is the wage and salary factor (IR1 = $11,142)$. The fifth is the access location factor (IR5 $=4.755$ ).

Testing the hypothesis, illustrated in Table 1, shows that all the testing components are declared significant (accepted). The partial second-order modeling test shows that the fundamental aspect dominates the role separately $(90.2 \%)$ in determining the decision to stay-intention for millennial employees in their company. The item of fundamental continuously controlled $84.9 \%$ by the psychological aspect. This means that the fundamental aspect as an element forming intention to stay for $90.2 \%$ employees can be realized as long as the psychology aspect factors control $84.9 \%$, an increase compared to the fundamental aspects following the rise in psychological factors. Likewise, the rational aspects of realizing decisions for intention to stay for employees contributed $87.9 \%$ as long as the fundamental aspects were met at least $93.2 \%$.

Table 1: Hypothesis Result

\begin{tabular}{|c|c|c|c|c|c|}
\hline & \begin{tabular}{|c|} 
Std \\
error
\end{tabular} & $\mathbf{t}$ & \begin{tabular}{|l|} 
Partial \\
Square
\end{tabular} & Sig & Result \\
\hline $\begin{array}{l}\text { Psychology } \\
\text { Aspect }\end{array}$ & 0.001 & 11.812 & $54,4 \%$ & \multirow{4}{*}{$<0.01$} & \multirow{6}{*}{ Accepted } \\
\hline $\begin{array}{l}\text { Fundamental } \\
\text { Aspect }\end{array}$ & 0.000 & 19.120 & $90,2 \%$ & & \\
\hline Rational Aspect & 0.000 & 10.375 & $87.9 \%$ & & \\
\hline \multicolumn{4}{|c|}{ Control Variable } & & \\
\hline \multicolumn{5}{|c|}{$\begin{array}{l}\text { Psychology Aspect } \leftarrow \rightarrow \text { Fundamental Aspect }= \\
0.849(\text { sig }<0.01)\end{array}$} & \\
\hline \multicolumn{5}{|c|}{$\begin{array}{l}\text { Fundamental Aspect } \leftarrow \rightarrow \text { Rational Aspect }= \\
0.932(\text { sig }<0.01)\end{array}$} & \\
\hline
\end{tabular}




\section{Discussion}

This study provides a comprehensive explanation of the principle of intention to stay decisions for millennial workers. Where it can be concluded that the three elements (psychology, fundamental and rational aspects) are the necessary components to decide on actions to stay working in their company. It is also clearly illustrated that the three elements are bound to one another. The study topics confirms and investigates the behavior of millennial workers It has provided a broad picture for understanding millennial workers from the social and psychology aspects of cognitive theory. Millennials as a productive generation are predicted to experience an explosion of productivity to occupy important positions at the level of middle up to upper management, which is now a hot topic of conversation and significant issues about their strengths and weaknesses related to work patterns. Work processes and achievement goals are challenges for this generation in the future. Corporate image is the primary concern in terms of rational aspects. It also assumes new hypotheses can be drawn as to the reasons why millennials tend to choose the place of work; the image/ prestige factor is considered to be an essential trigger in terms of psychological aspects. However, if it is associated with a dominant factor based on the rational aspect where the dominance of the construct is formed by the consideration of flexibility regulation and rules, this is undoubtedly anomal and counterproductive. Because of some of the main reasons why we declare this as a self-defeating statement:

- Generally, companies/organizations that are known to have a good image in the social environment naturally tend to have regulations/SOP (standard operational procedures) that are skewed tight. Measured based on KPI (key performance indicators), and rarely flexible, especially in terms of working time.

- Companies that have a right image of course already have a company size that is also large (e.g., scale, value, or volume of the company) or the company has been established for a long time, because the company image must be in line with the length of time the company/organization was established. The vocal point is companies with good corporate image models; of course, the top management is rarely found from the millennial generation. The babyboomers generation is dominant.

- Thinking paradigms and defining the working context between millennials vs. baby-boomers is a gap. Babyboomers assume productive work is primarily discipline (time discipline, management discipline, process discipline) to achieve measurable results. Whereas millennials define different disciplinary issues, and work, for millennials the definition of work relies on aspects of value and not size, results-oriented and not always process-oriented when deciding to start a job and when choosing to stop the work. The gap of mind-set and perspective of thinking is what will then become a gap between the desires of baby-boomers and millennials in one company.

The career development aspect of the item (IF7) is also a reason for the fundamental aspects of a millennials employee to decide on an intention to stay in their organization or company. The sense of wanting to be the center of attention, of course, is assumed to be a driver why aspects of career development are one of the main concerns, where the rapid pace of technology amidst business scope and companies require millennials to try to establish themselves in labor market competition. Of course, we can agree that millennials desire to take part with the help of technology. The positive side is that the great curiosity of millennials also confirms the aspects of career development are one of the main concerns. Because for millennials, every stage that passes is a place to promote themselves, and the character to introduce work methods from millennials are effective. Of course, this discussion section opens wide gaps for future discussion. Still, we only provide essential limitations in terms of the dominant factors forming items and variables to avoid biased and overly comprehensive discuss (see Appendix 4).

Job satisfaction factors, the desire to have a leader with a friendship leadership style, and a relatively consistent workload are also essential aspects desired by millennials. Of course, this also justifies many opinions, research, and even articles that state why millennials are considered lacking in loyalty character to work. Character traits of millennials are not always harmful, of course. There are positive things about millennials. The factor of no-bullying and no-harassment, safety factor during work, and training and development are the third priority concerns forming intention-to-stay decisions in this study. Especially the aspects of no-bullying and harassment including the issue of race, social-stratum, and ethnicity are hopes for millennials workers to be minimized or eliminated in a professional work environment. That is the positive side. Millennials grew up in an inclusive environment where information technology plays a role that grows along with the millennial generation. Every time global issues are presented, especially the issue of race and bullying, it makes millennials feel uneasy, so the millennials hopes that the problem of race, ethnic, and social-stratum should be eliminated. The concept of equality and no discrimination becomes jargon that often adorns the millennials' frame of life, and this is a definite idea, and should be applied to millennials.

Furthermore, social-life factors, management support systems, health facilities, work environments (e.g., organizational culture, employee relationships), wage and salary, service and turnover and access to the location to work are also serious considerations to keep in mind. Social life 
factors are related to organizational aspects and employee relationships. This concept is one of the definitions of work balance that is desired not only by millennials, but also by all persons. However, the conceptual social-life for millennials is not only a "face-to-face," social media life, and recreation is another meaning of the definition of socialization for millennials. Social-life is a stage for millennials to implement and show their achievements in their social environment. So this also justifies why the company/organizational images factor is most sought after for millennials to remain in their workplace because this is a component to express themselves amid the social environment. Likewise, are the factors of wage and salary, workload, health service and health facilities as rational and fundamental aspects.

\subsection{Theoretical Implication}

Previously, we have developed a conceptual model in the realm of behavior where the individual driving factors start from the three main principles, namely, normative, rationality, and emotionality. This study also developed the concept where the employee's decision underlying the intentionto-stay where he works is also based on the conceptual normative (fundamental aspect), rationality aspect, and emotionality (psychology aspect). In line with the results of this study, it also deals with several behavioral development theories that have been popularized by Bandura (Social Learning Theory), Social and Behavioral Contagion Theory (Gustave Le Bon, 1895), Robert Park and Herbert Blumer. Where Le Bon, Park, and Blumer agreed that in theory of responding, behavior arises from a stimulus. Regarding this opinion, this study provides an understanding that the intention to stay for employees, especially millennials in the categories as described in the method section, is interrelated and inseparable between the dominance of fundamental, psychology, and rational factors. Along with the modern motivational theory that has been popularized by Abraham Maslow, that physiological factors can reflect rational aspects, the need for security and safety can indicate the fundamental aspects, and the need for love, respect, and selfactualization can be included in the psychological aspects. This study also provides a novelty on the development of theories in psychology, social, or behavior, which, of course, has a positive impact on scholars to discuss and develop this element.

\subsection{Managerial Implication}

This study maps the universal results for stakeholders and HRM managers to be able to understand the behavior of millennials workers as well as one of the bases in determining the company's strategy in maintaining performance and ideas to start the process of recruiting millennial employees to the stage of retaining millennials employees in the company. Of course, this study is beneficial for managers with the majority of production activities involving millennials workers.

\section{Conclusions}

Studies initiated from the standpoint of behavioral, social, psychological, and motivational theories map out some conclusions where the fundamental, psychology and rational aspects of millennial workers are related to each other. As the next generation of baby-boomers takes the leadership position in the future, psychology, change in leadership style and patterns, as well as conducive job strategies and work conditions, need serious attention to prepare this millennial generation of future leaders and professionals.

\section{References}

Ahmat, C.N.H., Arendt, S. W., \& Russell, D. W. (2019). Effects of minimum wage policy implementation: Compensation, work behaviors, and quality of life. International Journal of Hospitality Management, 81(3), 229-238. https://doi. org/10.1016/j.ijhm.2019.04.019

Amponsah, T. K., Ntow, M. A. O., \& Mensah, J. (2016). Occupational Health and Safety Management and Turnover Intention in the Ghanaian Mining Sector. Safety and Health at Work, 7(1), 12-17. https://doi.org/10.1016/j.shaw.2015.08.002

Bahjat, E., Aljawazneh, B., Moh, Z., Smadi, A., \& Ziad, S. (2017). Workplace Bullying as a Predictor of Intention to Leave among Workers at the Industrial Organizations in Jordan. International Journal of Academic Research in Economics and Management Sciences, 6(2), 15-39. https://doi.org/10.6007/IJAREMS/v6i1/2559

Bartlett, J. E., \& Bartlett, M. E. (2011). Workplace bullying: An integrative literature review. Advances in Developing Human Resources, 13(1), 69-84.

Bayarçelik, E. B., \& Findikli, M. A. (2016). The Mediating Effect of Job Satisfaction on the Relation Between Organizational Justice Perception and Intention to Leave. Procedia - Social and Behavioral Sciences, 235(4), 403-411. https://doi. org/10.1016/j.sbspro.2016.11.050

Borges, N. J., Manuel, R. S., Elam, C. L., \& Jones, B. J. (2010). Differences in motives between Millennial and Generation X medical students. Medical Education, 44(6), 570-576. https:// doi.org/10.1111/j.1365-2923.2010.03633.x

Bozionelos, N., Lin, C.H., \& Lee, K.Y. (2019). Enhancing the sustainability of employees' careers through training: The roles of career actors' openness and of supervisor support. Journal of Vocational Behavior, 10, 33-43. https://doi.org/10.1016/j. jvb.2019.103333

Brown, M. E., Treviño, L. K., \& Harrison, D. A. (2005). Ethical leadership: A social learning perspective for construct development and testing. Organizational Behavior and Human 
Decision Processes, 97(2), 117-134. https://doi.org/10.1016/j. obhdp.2005.03.002

Burdin, G., \& Pérotin, V. (2019). Employee representation and flexible working time. Labour Economics, 61, (10),17-55. https://doi.org/10.1016/j.labeco.2019.101755

Chen, Y. Y., Park, J., \& Park, A. (2012). Existence, relatedness, or growth? Examining turnover intention of public child welfare caseworkers from a human needs approach. Children and Youth Services Review, 34(10), 2088-2093. https://doi.org/10.1016/j. childyouth.2012.07.002

Chin, W. (1998). The partial least squares approach to structural equation modeling. Modern Methods for Business Research, 295(2), 295-336. https://doi.org/10.1016/j.aap.2008.12.010

Chung, E. K., Jung, Y., \& Sohn, Y. W. (2017). A moderated mediation model of job stress, job satisfaction, and turnover intention for airport security screeners. Safety Science, 98(4), 89-97. https://doi.org/10.1016/j.ssci.2017.06.005

Coetzee, M., \& van-Dyk, J. (2017). Workplace Bullying and Turnover Intention: Exploring Work Engagement as a Potential Mediator. Psychological Reports, 121(2), 375-392. https://doi. org/10.1177/0033294117725073

Coloroso, B. (2006). The Bullying, The Bullied, And The Bystander (pp 1-218). New York, NY: Chapin Company.

Dingler, A., \& Enkel, E. (2016). Socialization and innovation: Insights from collaboration across industry boundaries. Technological Forecasting and Social Change, 109(3), 50-60. https://doi.org/10.1016/j.techfore.2016.05.017

Elçi, M., Şener, İ., Aksoy, S., \& Alpkan, L. (2012). The Impact of Ethical Leadership and Leadership Effectiveness on Employees' Turnover Intention: The Mediating Role of Work Related Stress. Procedia - Social and Behavioral Sciences, 58(4), 289-297. https://doi.org/10.1016/j.sbspro.2012.09.1003

Emiroğlu, B. D., Akova, O., \& Tanrıverdi, H. (2015). The Relationship Between Turnover Intention and Demographic Factors in Hotel Businesses: A Study at Five Star Hotels in Istanbul. Procedia - Social and Behavioral Sciences, 207(4), 385-397. https://doi.org/10.1016/j.sbspro.2015.10.108

Fornell, C., \& Larcker, D. F. (1981). Structural equation models with unobservable variables and measurement error: Algebra and statistics. Journal of Marketing Research, 18(3) 382-388. https://doi.org/10.2307/3150980

Ghosh, A., \& Shum, C. (2019). Why do employees break rules? Understanding organizational rule-breaking behaviors in hospitality. International Journal of Hospitality Management, 81(3), 1-10. https://doi.org/10.1016/j.ijhm.2019.02.003

Goh, Z., Ilies, R., \& Wilson, K. S. (2015). Supportive supervisors improve employees' daily lives: The role supervisors play in the impact of daily workload on life satisfaction via workfamily conflict. Journal of Vocational Behavior, 89(3), 65-73. https://doi.org/10.1016/j.jvb.2015.04.009

Gursoy, D., Maier, T. A., \& Chi, C. G. (2008). Generational differences: An examination of work values and generational gaps in the hospitality workforce. International Journal of Hospitality Management, 27(3), 448-458. http://dx.doi. org/10.1016/j.ijhm.2007.11.002

Henseler, J., Dijkstra, T. K., Sarstedt, M., Ringle, C. M., Diamantopoulos, A., Straub, D. W., \& Calantone, R. J. (2014). Common Beliefs and Reality About PLS: Comments on Rönkkö and Evermann. Organizational Research Methods, 17(2), 182-209. https://doi.org/10.1177/1094428114526928

Holtemöller, O., \& Pohle, F. (2019). Employment effects of introducing a minimum wage: The case of Germany. Economic Modelling (Article in press). https://doi.org/10.1016/j. econmod.2019.10.006

Indahingwati, A., Launtu, A., Tamsah, H., Firman, A., Putra, A. H. P. K., \& Aswari, A. (2019). How Digital Technology Driven Millennial Consumer Behaviour in Indonesia. Journal of Distribution Science, 17(8), 25-34. http://dx.doi.org/10.15722/ jds.17.08.201908.25

Jaworski, C., Ravichandran, S., Karpinski, A. C., \& Singh, S. (2018). The effects of training satisfaction, employee benefits, and incentives on part-time employees' commitment. International Journal of Hospitality Management, 74(3), 1-12. https://doi. org/https://doi.org/10.1016/j.ijhm.2018.02.011

Jennifer, D., Cowie, H., \& Ananiadou, K. (2003). Perceptions and experience of workplace bullying in five different working populations. Aggressive Behavior, 29(6), 489-496. https://doi. org/10.1002/ab.10055

Jiang, H., \& Shen, H. (2018). Supportive organizational environment, work-life enrichment, trust and turnover intention: A national survey of PRSA membership. Public Relations Review, 44(5), 681-689. https://doi.org/10.1016/j.pubrev.2018.08.007

Kim, H., \& Kao, D. (2014). A meta-analysis of turnover intention predictors among U.S. child welfare workers. Children and Youth Services Review, 47(4), 214-223. https://doi. org/10.1016/j.childyouth.2014.09.015

Koffka, K. (2013). Principles of Gestalt psychology (pp. 1-736). Abingdon, United Kingdom: Pychology Press, Routledge.

Kokoroko, E., \& Sanda, M. A. (2019). Effect of Workload on Job Stress of Ghanaian OPD Nurses: The Role of Coworker Support. Safety and Health at Work, 10(3), 341-346. https:// doi.org/10.1016/j.shaw.2019.04.002

Kumar, D., \& Govindarajo, N. (2014). Instrument Development "Intention to Stay Instrument" (ISI). Asian Social Science, 10(12), 149-169 . https://doi.org/10.5539/ass.v10n12p149

Lee, R., \& Wilbur, E. R. (1985). Age, education, job tenure, salary, job characteristics, and job satisfaction: A multivariate analysis. Human Relations, 38(8), 781-791. http://dx.doi. org/10.1177/001872678503800806

Li, N., Zhang, L., Xiao, G., Chen, J., \& Lu, Q. (2019). The relationship between workplace violence, job satisfaction and turnover intention in emergency nurses. International Emergency Nursing, 45(2), 50-55. https://doi.org/10.1016/j. ienj.2019.02.001

Lowe, D., Levitt, K., \& Wilson, T. (2011). Solutions for retaining generation $\mathrm{Y}$ employees in the workplace. IEEE Engineering 
Management Review, 39(2), 46-52. https://doi.org/10.1109/ EMR.2011.5876174

MacIntosh, E. W., \& Doherty, A. (2010). The influence of organizational culture on job satisfaction and intention to leave. Sport Management Review, 13(2), 106-117. https://doi. org/10.1016/j.smr.2009.04.006

McPhail, C. (1989). Blumer's Theory of Collective Behavior: The Development of a Non-Symbolic Interaction Explanation. The Sociological Quarterly, 30(3), 401-423.

Meiyani, E., \& Putra, A. H. P. K. (2019). The relationship between islamic leadership on employee engagement distribution in FMCG industry: Anthropology business review. Journal of Distribution Science, 17(5), 19-28. http://dx.doi.org/10.15722/ jds.17.05.201905.19

Myers, K. K., \& Sadaghiani, K. (2010). Millennials in the Workplace: A Communication Perspective on Millennials' Organizational Relationships and Performance. Journal of Business and Psychology, 25(2), 225-238. https://doi. org/10.1007/s10869-010-9172-7

Ng, E., Schweitzer, L., \& Lyons, S. (2010). New Generation, Great Expectations: A Field Study of the Millennial Generation. Journal of Business and Psychology, 25(2), 281-292. https:// doi.org/10.1007/s10869-010-9159-4

Olweus, D., \& Limber, S. P. (2010). The Olweus Bullying Prevention Program: Implementation and evaluation over two decades. In S. R. Jimerson, S. M. Swearer, \& D. L. Espelage (Eds.), Handbook of bullying in schools: An international perspective (pp. 377-401). New York, NY, US: Routledge/ Taylor \& Francis Group.

Robbins, S. P., \& Judge, T. A. (2008). Perilaku organisasi edisi ke12. Jakarta, Indonesia: Salemba Empat.

Rosario, H. E., Millán, L., Ramos, J., Cruz, M., Vélez, E., Torres, G., \& Rodríguez, N. (2018). Effect of the Exposure to Workplace
Bullying on Turnover Intention and The Mediating Role of Job Satisfaction, Work Engagement, and Burnout. Revista Interamericana de Psicología Ocupacional, 37(3), 26-51. https://doi.org/10.21772/ripo.v37n1a03

Saam, N. J. (2010). Interventions in workplace bullying: A multilevel approach. European Journal of Work and Organizational Psychology, 19(1), 51-75. http://dx.doi. org/10.1080/13594320802651403

Shao, Y., Nijstad, B. A., \& Täuber, S. (2019). Creativity under workload pressure and integrative complexity: The doubleedged sword of paradoxical leadership. Organizational Behavior and Human Decision Processes. (in press). https:// doi.org/10.1016/j.obhdp.2019.01.008

Sharma, G. G., \& Stol, K.-J. (2020). Exploring onboarding success, organizational fit, and turnover intention of software professionals. Journal of Systems and Software, 159, 110442. https://doi.org/10.1016/j.jss.2019.110442

Spence, K. W. (1950). Cognitive versus stimulus-response theories of learning. Psychological Review, 57(3), 159-172. http:// dx.doi.org/10.1037/h0058250

Walsh, G. (2019). Service employees' naturally felt emotions: Do they matter? European Management Journal, 37(1), 78-85. https://doi.org/10.1016/j.emj.2018.06.008

Wang, D., Hom, P. W., \& Allen, D. G. (2017). Coping with newcomer "Hangover": How socialization tactics affect declining job satisfaction during early employment. Journal of Vocational Behavior, 100(3), 196-210. https://doi. org/10.1016/j.jvb.2017.03.007

Zhang, X., Ma, L., Xu, B., \& Xu, F. (2019). How social media usage affects employees' job satisfaction and turnover intention: An empirical study in China. Information \& Management, 56(6), 103136. https://doi.org/10.1016/j.im.2018.12.004 
Appendix 1: Variables and Measurement

\begin{tabular}{|c|c|c|c|c|}
\hline Variable & Item & Construct & Code & Major References \\
\hline \multirow{3}{*}{$\begin{array}{l}\text { Millennials } \\
\text { Employee } \\
\text { Intention to } \\
\text { Stay }\end{array}$} & $\begin{array}{l}\text { Psychology } \\
\text { Aspect }\end{array}$ & $\begin{array}{l}\text { - No bullying and harassment } \\
\text { - Job Satisfaction } \\
\text { - Socialization } \\
\text { - Organization Images }\end{array}$ & $\begin{array}{l}\text { IP2 } \\
\text { IP6 } \\
\text { IP7 } \\
\text { IP8 }\end{array}$ & \multirow{3}{*}{$\begin{array}{l}\text { (Coetzee \& van Dyk, 2017), } \\
\text { (Bahjat et al., 2017), (Rosario- } \\
\text { Hernandez et al., 2018), } \\
\text { (AbuAIRub et al., 2016), (Zhang et } \\
\text { al., 2019), (Bayarçelik \& Findikli, } \\
\text { 2016) } \\
\text { (Dingler \& Enkel, 2016) } \\
\text { (Sharma \& Stol, 2020), (Wang } \\
\text { et al., 2017), (Che Ahmat et } \\
\text { al., 2019), (Goh et al., 2015), } \\
\text { (Kokoroko \& Sanda, 2019), (Shao } \\
\text { et al., 2019), (Burdin \& Pérotin, } \\
\text { 2019), (Ghosh \& Shum, 2019), } \\
\text { (Walsh, 2019), (Bozionelos, Lin, \& } \\
\text { Lee, 2019), (Jaworski et al., 2018), } \\
\text { (Brown, Trevino, \& Harrison, 2005), } \\
\text { (Kim \& Kao, 2014) and (Chen et } \\
\text { al., 2012). . }\end{array}$} \\
\hline & $\begin{array}{l}\text { Fundamental } \\
\text { Aspects }\end{array}$ & $\begin{array}{l}\text { - } \quad \text { Have high management relationship } \\
\text { - } \quad \text { Management support systems } \\
\text { - } \quad \text { Sapervisor and leadership more friendship } \\
\text { - } \quad \text { Welfare Service and turnover } \\
\text { - } \quad \text { Health facility } \\
\text { - Organizational Culture, Work-environment, } \\
\quad \text { Employee Relationship }\end{array}$ & $\begin{array}{l}\text { IF1 } \\
\text { IF2 } \\
\text { IF3 } \\
\text { IF4 } \\
\text { IF5 } \\
\text { IF6 } \\
\text { IF7 }\end{array}$ & \\
\hline & $\begin{array}{l}\text { Rational } \\
\text { Aspects }\end{array}$ & $\begin{array}{l}\text { - Wage and Salary } \\
\text { - } \quad \text { Workload } \\
\text { - } \quad \text { Flexibility regulation and rules } \\
\text { - } \quad \text { Work Access Location }\end{array}$ & $\begin{array}{l}\text { IR1 } \\
\text { IR2 } \\
\text { IR3 } \\
\text { IR4 } \\
\text { IR5 }\end{array}$ & \\
\hline
\end{tabular}

Appendix 2: Analysis Result Second-order model

\begin{tabular}{|c|c|c|c|c|c|c|c|c|c|}
\hline \multirow{2}{*}{ Construct } & \multicolumn{3}{|c|}{ Frequency } & \multirow{2}{*}{ Loadings } & \multirow{2}{*}{$\begin{array}{l}\text { Discriminant } \\
\text { Validity }\end{array}$} & \multirow{2}{*}{ VIF } & \multirow{2}{*}{ Result Item } & \multirow{2}{*}{$\begin{array}{c}\text { std. } \\
\text { deviation }\end{array}$} & \multirow{2}{*}{$\begin{array}{c}\text { Result } \\
\text { Variable }\end{array}$} \\
\hline & Mean & Med & Std. Dev & & & & & & \\
\hline $\begin{array}{l}\text { IP2 } \\
\text { IP6 } \\
\text { IP7 } \\
\text { IP8 }\end{array}$ & $\begin{array}{l}6.00 \\
5.54 \\
5.75 \\
5.96\end{array}$ & $\begin{array}{l}6.00 \\
6.00 \\
6.00 \\
6.00\end{array}$ & $\begin{array}{l}0.888 \\
1.058 \\
1.226 \\
1.118\end{array}$ & $\begin{array}{l}0.732 \\
0.785 \\
0.943 \\
0.949\end{array}$ & 0.874 & $\begin{array}{l}1.135 \\
1.024 \\
2.062 \\
1.048\end{array}$ & $\begin{array}{l}\text { Psychology } \\
\text { Aspect (IP) } \\
\text { CR }=0.676 \\
\text { Loadings }=0.298 \\
\text { Alpha }=0.674 \\
\text { AVE }=0.855\end{array}$ & 0.025 & \multirow{3}{*}{$\begin{array}{l}\text { Intention to } \\
\text { stay (ITS) } \\
\text { CR }=0.921 \\
\text { Alpha }=0.880\end{array}$} \\
\hline $\begin{array}{l}\text { IF1 } \\
\text { IF2 } \\
\text { IF3 } \\
\text { IF4 } \\
\text { IF5 } \\
\text { IF6 } \\
\text { IF7 }\end{array}$ & $\begin{array}{l}5.58 \\
5.99 \\
5.95 \\
5.82 \\
5.91 \\
5.64 \\
5.93 \\
\end{array}$ & $\begin{array}{l}6.00 \\
6.00 \\
6.00 \\
6.00 \\
6.00 \\
6.00 \\
6.00 \\
\end{array}$ & $\begin{array}{l}1.173 \\
1.020 \\
1.086 \\
1.077 \\
1.045 \\
1.150 \\
1.018 \\
\end{array}$ & $\begin{array}{l}0.655 \\
0.792 \\
0.871 \\
0.867 \\
0.729 \\
0.697 \\
0.888 \\
\end{array}$ & 0.790 & $\begin{array}{l}1.433 \\
2.649 \\
2.970 \\
2.131 \\
2.125 \\
2.072 \\
1.940 \\
\end{array}$ & $\begin{array}{l}\text { Fundamental } \\
\text { Aspect (IF) } \\
\text { CR }=0.920 \\
\text { Loadings }=0.602 \\
\text { Alpha }=0.897 \\
\text { AVE }=0.624\end{array}$ & 0.030 & \\
\hline $\begin{array}{l}\text { IR1 } \\
\text { IR2 } \\
\text { IR3 } \\
\text { IR4 } \\
\text { IR5 }\end{array}$ & $\begin{array}{l}4.79 \\
5.17 \\
4.83 \\
4.94 \\
5.68\end{array}$ & $\begin{array}{l}4.00 \\
5.00 \\
4.50 \\
5.00 \\
6.00\end{array}$ & $\begin{array}{l}1.365 \\
1.248 \\
1.319 \\
1.286 \\
1.278\end{array}$ & $\begin{array}{l}0.755 \\
0.802 \\
0.828 \\
0.784 \\
0.502\end{array}$ & 0.744 & $\begin{array}{l}2.450 \\
2.463 \\
1.507 \\
1.746 \\
1.064\end{array}$ & $\begin{array}{l}\text { Rational Aspect } \\
\text { (IR) } \\
\text { CR }=0.858 \\
\text { Loadings }=0.355 \\
\text { Alpha }=0.787 \\
\text { AVE }=0.755\end{array}$ & 0.032 & \\
\hline
\end{tabular}


Appendix 3: t-statistics result

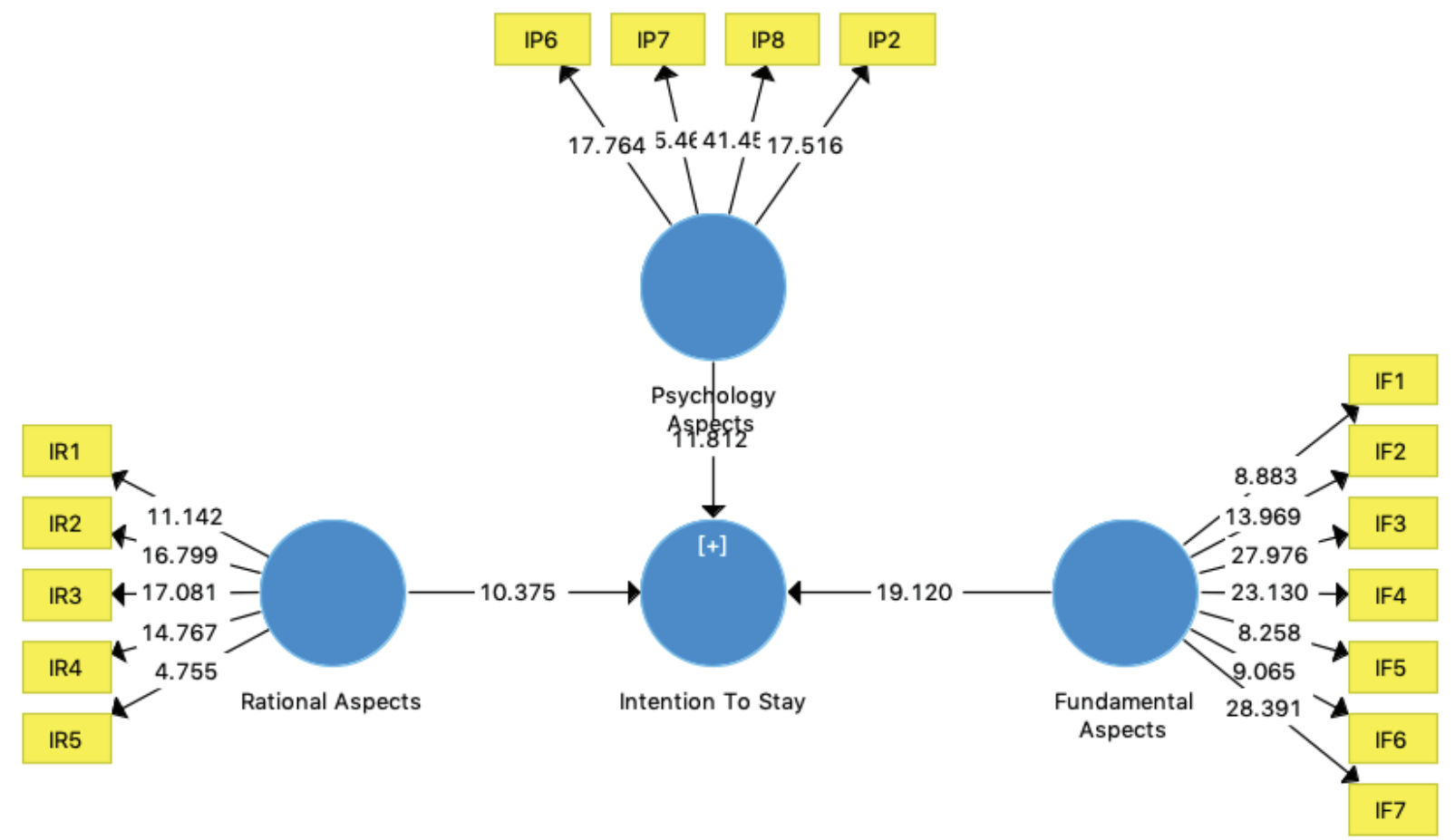

Appendix 4: Rules of Third Millennials Work-Intention to Stay

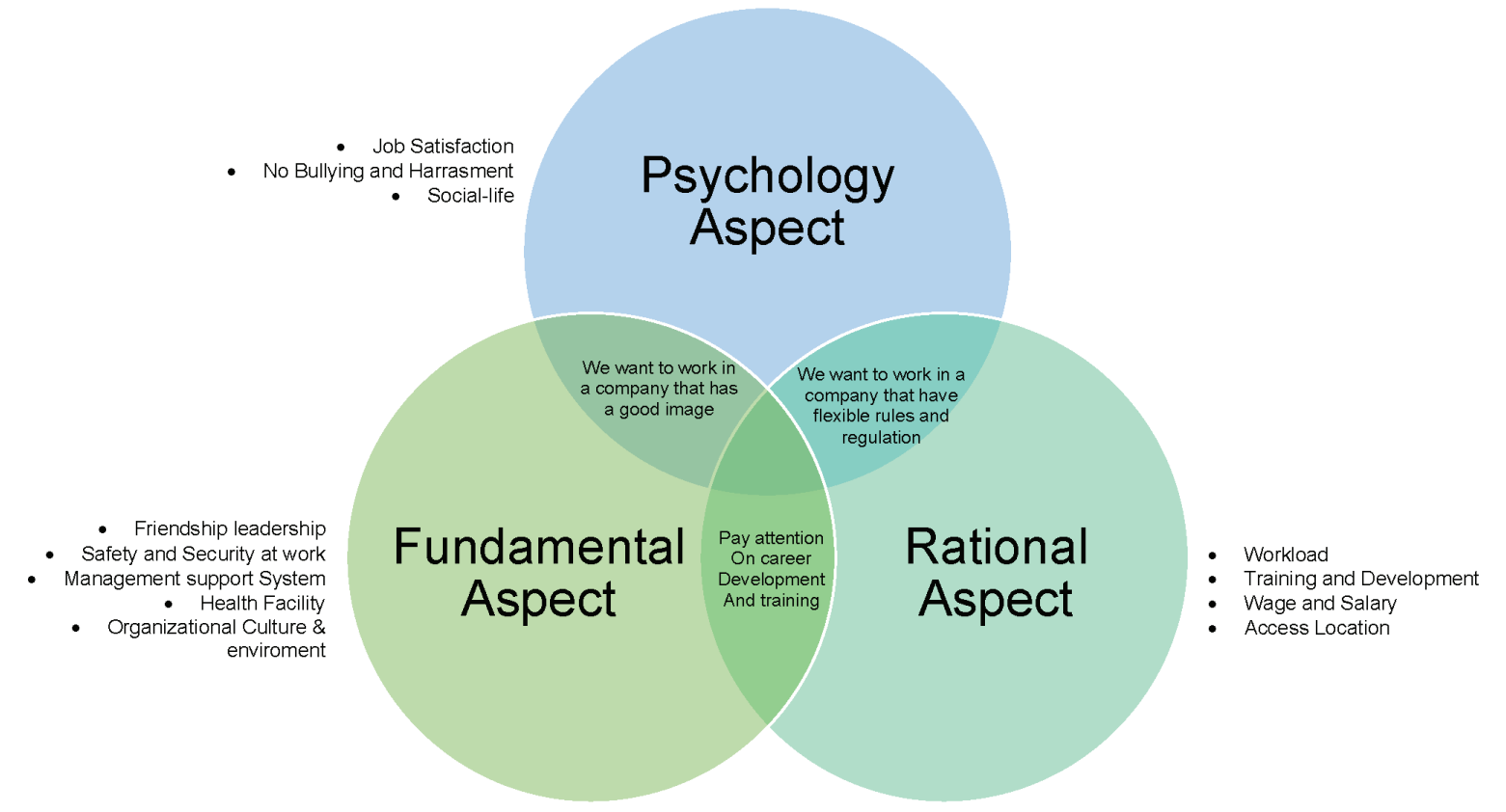

Source: Authors, 2019 
